\title{
Mobile Application System Supported BUC Students Services and Learning
}

\author{
https://doi.org/10.3991/ijim.v14i09.12053
}

\author{
Ghaliya Al Farsi ${ }^{\bowtie}$, Jasiya Jabbar, Ragad M Tawafak, \\ Sohail Iqbal Malik, Abir Alsidiri, Maryam Alsinani \\ Al Buraimi University College, Al Buraymi, Oman \\ galfarsi@buc. edu.om
}

Hidayah bte Sulaiman

University Tenaga, Kajang, Malaysia

\begin{abstract}
Smartphones and applications plays a significant role in learning and management systems. Mobile application system was usually demanded, especially college students are always looking for things that benefit them at a university, even though the current applications were efficient enough to achieve a high level of supporting students learning needs. In this research, there is a requirement to implement a new application system for student education service with an easy way of managing data for educational purposes to reduce and save the time for search of traditional methods. This research method is based on surveying with the students of Al Buraimi University College (BUC). The findings of this survey reveal a positive result when they used the new proposed model, thus the goal was achieved and as a result of this research a new mobile application was developed which replaces several applications.
\end{abstract}

Keywords - Smartphones, Mobile application, College Students, internet services.

\section{Introduction}

Cell phones are not anymore only a method for talking. With the improvement of present-day innovation, cell phones have been added to the new function. Over the past few years, cell phones have turned into a basic piece of the lives of many millions around the world and are the fundamental wellspring of incomes and benefits of significant organizations. All organizations are approved to make an application and can distribute it to encourage and facilitate numerous activities. Researchers demonstrate the importance of using modern technologies early for students to the ability of the student in the early stages of education to absorb and develop skills. As other studies have also demonstrated that strengthening curricula such as developing games and scratch led to a clear increase in performance and helped the teacher in programming languages overcome previous programming difficulties [1] [2]. 
The researchers explained in this study that the student responds and prefers to use the module and access educational materials through mobile phones and not through the computer for fast access to the model and the constant availability of the mobile phone. The permanent and continuous student interaction, skills, and culture that the student has by using the Internet via mobile phones. In this study did not prefer using [3].

Papadakis, S. (2018) presented that a mobile is an important tool in an educational institution [4]. Sohail et al (2013) introduced an m-learning application in a programming course at BUC [5]. The advanced features of mobile applications make day-to-day activities quick and easy and thus mobiles and mobile applications are vital and obligatory in today's fast running life. The use of mobile applications has a wide scope from the utility, productivity, and navigation to entertainment, sports, fitness, and just about any others imaginable.

Universities and colleges have advanced applications that help teachers and employees to access services more easily and students in particular. They are the main nucleus in any educational institution. In this sense, we have established an application to serve this purpose and facilitate its academic activities. The mobile phone is used in $99 \%$ of universities and nowadays there are no students who do not have mobile and mobile applications will facilitate the process of learning and save time [6] [7].

Tawafak, et al. also mentioned that the use of applications and technologies with high level of development can enhance the student performance and their interest to increase their technical skills [51, 53, 49, 55]. Beranek, et al, 2017 promote the adoption of using learning management system can be used in mobile to manage the control and data influence in small or medium universities [56].

The students get to know about the news and events of college through notice boards. Some students don't follow-up these are unaware of the activities held in college. There is also a mobile application called BUC news which circulates all activities in college, some students and teachers depend on it [6]. For the students, to get information about different majors hosted in college, their study plans, etc. they have to check for the college website. If the students need to know about exams, they check notice boards or once a student gets to know, they circulate it in social media. Tawafak, et al, 2020, explain in a development model of e-learning system that using multimedia techniques through the semester of student learning can help them to improve the university outcomes as management level. Beside the student experience in using these technologies as login to Instagram or face-book to share their feedback on each phase of their learning process.

The student also suffers from problems of portals sometimes where the students see their transcript and through which students can register for courses in every semester.

They also face difficulty in knowing the places and departments in the college for students in general and new students in particular.

This research aims to help and facilitate the student for a variety of tasks. As students are a font of smartphones and wifi is easily available and cheap, they prefer mobile applications supporting their needs. Some of the functions are already done electronically using the website or mobile applications. As a result of this research new mobile application is developed that replaces several applications. 
The objectives of this application are:

- To include all the latest news of Al Buraimi University College

- To include all programs offered in the college and the information related to each proposed degree of diploma, advanced diploma and bachelor.

- To include midterm exam and final exam schedules with details and important dates and times for each scheduled exam.

- To interact with the library through college e-library system of portal.

- To guide the student on this/her academic status and to follow up the calculate GPA after each semester completion.

- To generate a location map for every spot of college and thereby ease searching rooms.

The major advantage of this application is the multitasked support it provides. Instead of using six different means, all the above features are bound together in one application which makes students comfortable. Besides that, this application can be offered in two languages as Arabic and English versions [50]. Furthermore, this application shows the information progression easily and pronounced in a sequence that become very clear for the students.

This article is organized into several sections. It starts with a literature review collected from database of open access articles. Second the discussion of the methodology used in developing an application, this application has integrated features and services to help the students. Fourth, furthermore development of the application with various screenshots to explain its working and finally the evaluation of the system. The paper concludes with a summary of the research work, the limitations and future enhancement of the work.

\section{$2 \quad$ Literature Review}

Ferriter and Garry said that the student's study habits are constantly changing due to the smartphones owning by the majority of them. The information systems community and individuals working in education know that this technology can positively impact a college student's education [8].

In [9], the researcher's study found that over $80 \%$ of the population has purchased a smartphone and how students use their phone differs from the traditional phones were designed to be used previously.

In [10], researchers considered four main things in their study which are: determining the preferred Mobile Operating System among students in the college, Applications used among them, the main app used, and mostly used social media apps. This explanatory study yielded four significant findings; Android preferred Operating System, 25 apps installed, most useful apps are Utility Apps; least useful are Travel Apps, mostly used are Social Media, open Primary app 6 times a day, and Facebook is the primary social media app. Although this is scary and not practicing safety, features like these on apps are being used continually by many students in the college to show exactly where they are going for their friends. 
Peterson (2011) stated that the apps are a portable way to stay connected to social media and $97 \%$ of smartphone users use apps for social networking purposes. Furthermore, smartphone social media apps give the user the ability to check their social media sites anywhere, anytime instead of having to sit in front of their computer screen [11].

Sarrab (2015) the researchers said that Mobile learning is a new research area, that has become a newly-visible tool for our (group of schools/way of teaching). The mobile learning can be used to improve the overall learning experience of our students and teachers. They present the M-learning approach as the next generation of eLearning, whereas the next generation of the learning systems will provide easy access and widely available to all who wish to be part of it. Also, they highlight the benefits and future challenges of mobile learning in the educational surrounding conditions [12].

In [13], the studies show social network apps are used by $97 \%$ of smartphone users. The apps provide the availability of social media anytime and anywhere. As smartphones are portable social media sites can be accessed from any place instead of sitting in front of the desktop or laptop. The results of the study show that the majority of students possess smartphones and the current trend of studying is changing due to the regular use of it. The development of technology also supports this fact and has to admit the positive impact of these in the education sector.

In [14], researchers said that these mobile applications help not only students in colleges but also all people. It solves problems for many people, assists people with disabilities in their tasks so they can their tasks with no help from others. Also, jobs were created as designers, developers and so many.

This paper proposed a new Mobile app with some additional services to assist BUC students in the college and even outside the college. The advantages of this application can be listed as providing easy access through mobile, the number of services offered are totally important for student skills development. Furthermore, the student experience and enhance interest of learning the courses objectives, sequences, and the way of studying course to increase their total average and give them chances to evaluate and assess through their feedback with the management level. This app has added value to the students beside the previously developed app which are listed in this section.

\section{Methodology}

To develop this application, prototyping methodology was used. The requirements of the system were collected in the analysis phase. The quick design of the system was developed followed by analysis using the Android studio. Later a prototype was developed by connecting the interfaces and database. The prototype was refined and more features were added and, in the end, the evaluation of the system was also conducted.

In the analysis, a survey was conducted to understand the need and requirements of the application. Initially, a study was made to understand what all functions to be included in the application. Followed by this the survey was conducted focusing on the functions that were intended to be added in the application. The survey was distributed 
to 35 participants to collect all the requirements of the system to be implemented. The participants were students from Buraimi University College itself. The participants filled the survey after the idea of the research were explained to them. According to the results of the questionnaire analysis, it is very clear from students' answers that they think it is good to have an application to help them solve problems and provide them with the ability to get their service comfortably and quickly.

Android studio was used for interface design and the SQLite database was used to build a database for the application. After developing and refining the application, the final version was given for $\beta$-testing. In $\beta$-testing, the application was installed in a sample of students and a questionnaire was distributed to collect their feedback on the application. The result of the questionnaire analysis showed that the application was beneficial up to student's expectations.

\section{Development}

Based on the result of the survey, which indicates that students need this program which will facilitate them a lot of the services needed by the student and time. In the design, the phase relates to the physical construction of the system. It contains the design of the system (hardware, software, logic of functions working, consistence of services, programming language, etc.), also the design of user interface (forms, reports, etc.), the design of the system interface that allows the system to communicate with another system, and security problems that face the system during the work. It is important to test the proposed design for performance and ensure that it meets the requirements in the analysis phase. In other words, the main objective of this stage is to convert the predefined requirements into a set of specifications that will be used for the next phase.

\section{Tools and Programs Used}

Android studio was the main integrated development environment, using an XML framework as the targeted framework for the application, using JAVA programming language. Also, we use the Edraw max program to analyses context diagrams, Microsoft Word to write the document, and YouTube to learn more about Android studio language. And Genymotion to install the program.

1. Android studio: We used the Android Studio 2018 community edition version 3.2.1, which is a free version with all necessary components for our research.

2. XML framework: Many of programmer they use XML in creating applications with all data produced. defines and produces pure data in XML. 


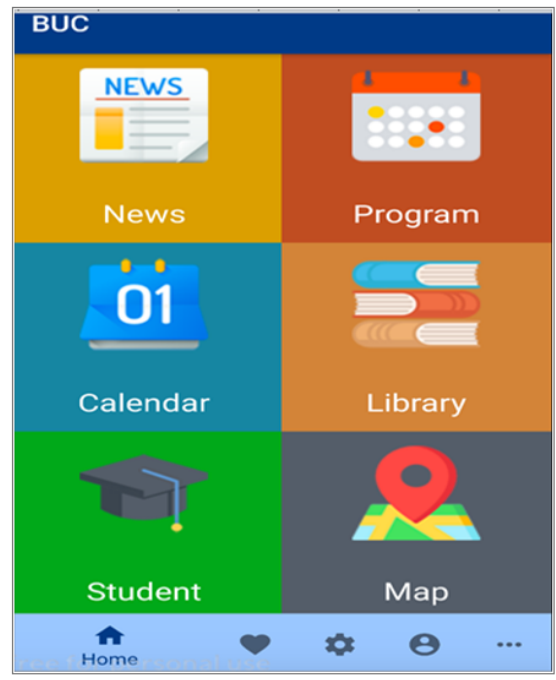

Fig. 1. StoryBoard- Main form

3. JAVA programming language: It was a general-purpose of computer programming language, it is one of the oldest languages introduced in 1995 by James Gosling. Here we use it to make our application.

Figure 1 have the full story-board of this mobile application. The first label includes the name of the system as system logo. Label 2 include the news, where all BUC news will raise sequentially through bar-tool in a sequence of importance and based on earliest dates. Label 3 contains the programs that are offered in each department within its different majors and different degrees. Label 4, the calendar shows both midterm exam and final term exam schedules. In addition to this, this section also includes the full academic calendar with all important dates and holidays within each semester. From the library menu, label 5 the students are authorized to access to BUC electronic library that have thousands of e-journals, e-books, and e-magazine. Label 6, shows the level is the student, were all individual student access can view his/her full information, major, address, finished courses, advanced courses, number of elective courses and the accumulated average for graduation needs. Label 7, the map label at the bottom of the user interface include location map for every spot of college. The other buttons in the user interface are the settings, services and the home icon to return to the home page.

In this part, we will clarify the application after Improvement In which our task exacted and assess. As shown in figure 1 there are many features such as we've added some simple adjustments like adding the alert feature in the Calendar icon. Through this application, the student can see his grade and calculate his cumulative average. They can also see the latest news of Al Buraimi University College and allows them to look at the types of program and information about it and registration that include your all courses you take it before until now also the payment request that allow you to pay for housing, tuition, housing damage. The calendar contains a special event like Exams time also the student can add an alert for any day, which will remind him of this event. 
In Program that you can select your program and you will see the information about the program.

In the student services label, you will see your Grade and also you can calculate your GPA, registration that includes your all courses you take it before until now also the payment request that allows you to pay for housing, tuition, housing damage.

In setting a label, you can rate the app also you will report your problem. If you have feedback you can send it also. Finally, it has about the BUC app. In the location label, you will be shown the location of the college. All these tasks add good services and assist the students in their learning.

\section{$6 \quad$ Result and Discussion}

\subsection{Pre-test}

The survey was distributed to (35) participants to collect all requirements of the system to be implemented during the design phase,

The participants filled the survey after the idea of the research were explained to them to grantee the results. The Tables 1,2,3 and 4 in appendix comes respectively shows the result of pre-questionnaire and the student feedbacks and their needs for easy and simple mobile application.

The analysis of Table 1 shows that no missing of any questionable also the mean result include the values 3.9 and above from the range 1 to 5 for all six questions that students need for the application to facilitate the process of learning.

Table 2 The reliability analysis was first passed out after 35 answers the result .964 . this value above $90 \%$, show that the questionnaire was reliable in collecting the information. While table 3 analysis of the six questions the values of variance between 0.0 to 0.5 .

Table 4 in the appendix, $F=7.497$ and the value of significance lies between $0 \%$ to $5 \%$ means that there is a need for the new integrated services within mobile application.

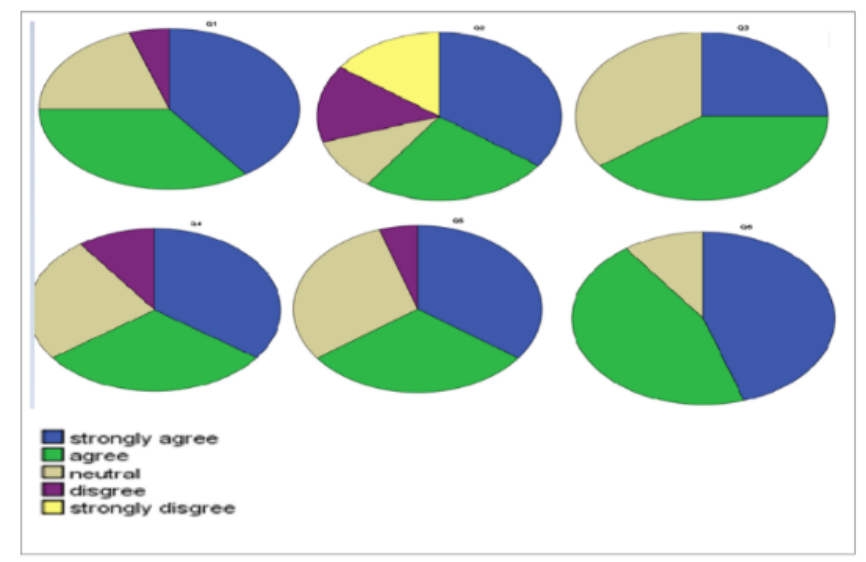

Fig. 2. Pie chart analysis of Pre-test 
Figure 2, shows the six survey questions and the answers through 5-point score of Likert sequence. This figure from the pre-questionnaire analysis collected BUC students to measure their interest towards the idea of producing an integrated application for university/ college students through mobile application. in table 9. It shows six different questions asking about the real problem and user need for the proposed model in a mobile application. This questionnaire used a Likert score of 5 points from 5: Strongly agree, 4: Agree, 3: Neither, 2: Disagree, 1: Strongly disagree In Q1, "The BUC student system can give easier access and flexibility in attendance follow up" there are 68 percent of students answers between strongly agree and agree. In Q2. "The BUC student help to fast GPA calculator", the answers limit between the highest two options reach to $62 \%$, in Q3. "Currently there is difficulty opening the portal to see you a time table for your materials?", the results of positive answers cross above $65 \%$. For Q4. "Is it difficult to search for a book from the college library site?", the results come between 4 options and high values give positively as $64 \%$. Also, Q5. "There is in BUC map?" give the same results as Q4 with percent 60\%. While Q6. "Is the study plan available with you at every moment or prefer an application to return to it at any time?", the best answer moved on strongly agree and agree and give $87 \%$ of agreement results.

According to the results of the questionnaire analysis, it is very clear from students' answers that they think it is good to have an application to help them solve problems and provide them with the ability to get their service comfortably and quickly. Based on the above results, we decided to continue the research and design the application according to users' expectations.

\subsection{Post-test}

The result of the second questionnaire

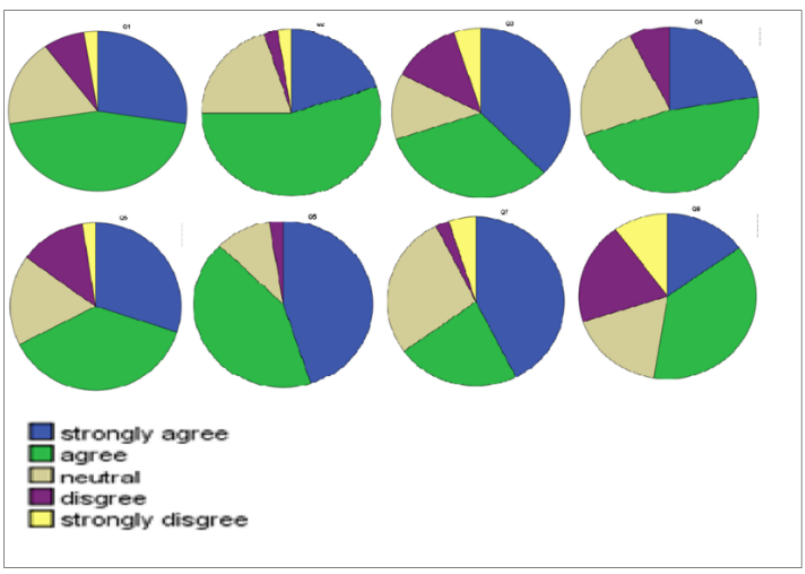

Fig. 3. Pie chart analysis of Post-test 
The post-test questionnaire included eight different questions adapted from different references as shown in table 10. Figure 3 shows the official student feedback of the post-test survey conducted after applying initial design for this application system. The student acceptance and interest to activate the application and used by all BUC students was revealed and emphasized in the analysis results.

\subsection{Scale: All variables}

The tables 5,6,7 and 8 show the result of the post-questionnaire that proves that all the students and satisfy with this application. The analysis of table 5 shows that no missing of any of 40 questionable also the result of the percentage of valid $100 \%$. for all eight questions that students satisfy from the application to facilitate the process of learning. Also, table 5, The reliability analysis was first passed out after 40 answers the result .840 . this value above $80 \%$, shows that the questionnaire was reliable in collecting the information. In table 8 shows that $\mathrm{F}=2.707$ and the value of significance lies between $0 \%$ to $5 \%$ means that all satisfied with the application.

After the studies and surveys, we conducted and the results of the first and second questionnaires were confirmed for our studies and proved that the application facilitated the student some things in his university life.

\section{Conclusion}

After following every one of the means and making the last framework, it is clear founded on the result of the questioners. it gave clear from students answer that the application helps them to solve the problem and provide them with the ability to get their service comfortably and quickly. that the goals have been cultivated, all outcomes show that the framework is well working, solid and proficient.

After the completion of this research, there are things we will modify. We will develop the program more than now. It will also be raised in the lifting sites to benefit any student who needs it. The good programs, which are established in a way that accepts the amendments and development. Research implementation of the college can be modified. It can be adopted by the college. We have achieved the goal of implementation as the questionnaire demonstrated student satisfaction through the questionnaire.

\section{References}

[1] S Papadakis, M Kalogiannakis, E Sifaki, and Vi, "Access Moodle Using Smart Mobile Phones. A Case Study in a Greek University," Computer Sciences, Social Informatics and Telecommunications, pp. 229, 376-385, 2018. https://doi.org/10.1007/978-3-319-76908$\underline{036}$

[2] P Dorouka, S Papadakis, and M Kalogiannakis, "Tablets \& apps for promoting Robotics, Mathematics, STEM Education and Literacy in Early Childhood Education," International 
Journal of Mobile Learning and Organisation, pp. 14,2, 255-274, 2020. https://doi.org/10.1504/ijmlo.2020.10026334

[3] Papadakis S, "Evaluating a game-development approach to teach introductory programming concepts in secondary education. ," Int. J. Technology Enhanced Learning, pp. 12(2), 127145, 2020. https://doi.org/10.1504/ijtel.2020.106282

[4] S Papadakis, "Evaluating pre-service teachers' acceptance of mobile devices with regards to their age and gendera case study in Greece," International Journal of Mobile Learning and Organisation, 12(4), vol. 12, no. 4, pp. 336-352, 2018. https://doi.org/10.1504/ ijmlo.2018.10013372

[5] M. Shakir, m. Yahya Abdu, S. Iqbal and A. K.H. Muttar A. Eldow, "Exploring the Extent of ICT Role as a teaching Tool in the Public Universities of Khartoum State," Journal of Engineering and Applied Science, vol. 13, no. 15, 2018.

[6] Ghaliya ALFarsi, Jasiya Jabbar, and Maryam ALSinani, "Implementing a Mobile Application News Tool for Disseminating Messages and Events of AlBuraimi University College," International Journal of Interactive Mobile Technologies (iJIM), vol. 12, no. 7, 2018. https://doi.org/10.3991/ijim.v12i7.9484

[7] M., Elsherif, H. M., \& Shaalan, K. Al-Emran, "Investigating attitudes towards the use of mobile learning in higher," 2016. https://doi.org/10.1016/j.chb.2015.11.033

[8] William M, Ferriter, and Adam Garry, "Teaching the iGeneration: 5 Easy Ways to Introduce Essential Skills with Web 2.0 Tools," in Using Web 2.0 in Teaching and Instruction.: Solution Tree Press, 2010.

[9] Dr.gayle R. Jesse, Smart phone and app usage among college student. North Carolina USA: wilmington, 2015.

[10] Dr.Gayle R.Jesse, Smartphone and App Usage Among College Students. North Carolina USA: Wilmington, 2015.

[11] D Peterson. (2019) Peterson, D. (2011, November 10). Stats on College Students \& their cellphones. Retrieved March 15, 2014, from Generation Mobile: http://thedrewpeterson. com.

[12] Mohamed Sarrab, "M-learning in education:Omani Undergraduate students perspective," Social and Behavioral Sciences, no. 176, pp. 834-839, 2015. https://doi.org/10.1016/ j.sbspro.2015.01.547

[13] Abdalla Eldow, Mohanaad Shakir, mohamad Yahya Abdu, Sohail Iqbal, and Ahmed K.H. Muttar, "Exploring the Extent of ICT Role as a teaching Tool in the Public Universities of Khartoum State," Journal of Engineering and Applied Science, vol. 13, no. 15, 2018.

[14] Tom Page, "Application-based mobile devices in design education," vol. 8, no. 2, 2014.

[15] Tawafak, Ragad M., et al. "E-learning Vs. Traditional Learning for Learners Satisfaction." E-learning 29.3 (2019): 388-397.

[16] Rajinder Singh, Journal of Engineering Research and Applications.: February, 2014.

[17] Narmatha M and Venkata KrishnaKumar S, "Study on Android Operating System And Its Versions," vol. 2, no. 2, 2016.

[18] Ahamed Shibly, "Android Operating System: Architecture, Security Challenges and Solutions," Sri Lanka, 2016.

[19] Kristen Diliberto Macaluso and Hughes Alan, "The Use of Mobile Apps to Enhance Student.," vol. 43, no. 1, 2016.

[20] N Newman, "Media Journalism and Technology Predictions," 2016.

[21] Mustafa Al-Emran and Sohail Malik, "The Impact of Google Apps at Work: Higher Educational Perspective. International," vol. 10, no. 4, 2016.

[22] "Mobile News Notifications," 2016.

[23] NIC Newman, "News Alerts and the Battle for the Lockscreen," 2018. 
[24] L. Ashwin Kumar, "Mobile Application for News and Interactive Services," vol. 2, no. 1, 2012.

[25] Joanna K. Law a, Parker A. Thome b, Brenessa Linde, "Student use and perceptions of mobile technology in clinical," The American Journal of Surgery, pp. 196-199, 2018.

[26] Paramasivam, Gurunathan, Manohar, and Iqbal Sohail, "Bringing Technology into The Class Room: Receptivity and Satisfaction Level of Faculty Members Using Smart Board An Experimental Study," in The 2nd International Conference on Applied Information and Communications Technology, 2014, pp. 274-279.

[27] Iqbal Sohail, M. U. Chowdhury, and O. K. Harsh, "Mobile devices supported learning for novice programmers," in Second International Conference on E-Learning and ETechnologies in Education (ICEEE), 2013, pp. 277-282. https://doi.org/10.1109/ icelete.2013.6644388

[28] Erinc Ercag Fezile Ozdamli, "Opinions of Teacher Candidates on the Usage of Mobile," vol. 12, no. 2, 2018.

[29] Vimala Balakrishnan Chin Lay Gan, "Enhancing classroom interaction via IMMAP - An Interactive Mobile Messaging App," vol. 34, 2017. https://doi.org/10.1016/j.tele. $\underline{2016.05 .007}$

[30] Ting-Hsuan Chen Mu-Yen Chen, "Modeling public mood and emotion: Blog and news sentiment and socio-economic phenomena," no. https://doi.org/10.1016/j.future. $\underline{2017.10 .028}$

[31] Tanja Svarre, "Designing a Mobile Application for Structured and Flexible Interview Data Collection in the Health Domain," vol. 12, no. 3, 2018. https://doi.org/10.3991/ ijim.v12i3.8232

[32] Mahardeka Tri Ananta,Lutfi Fanani, Komang Candra Brata, Nurizal Dwi Priandani Ratih Kartika Dewi, "The Development of Mobile Culinary Recommendation System Based on Group Decision Support System," vol. 12, no. 3, 2018. https://doi.org/10.3991/ ijim.v12i3.7799

[33] Ahmad Sanmorino and Ricky Maulana Fajri, "The Design of Notification System on Android Smartphone for Academic Announcement," vol. 12, no. 3, 2018. https://doi.org/10.3991/ijim.v12i3.8494

[34] Agathi Stathopoulou, Zoe Karabatzaki, Alexandra Economou, and Athanasios Drigas, "Mobile Assessment Procedures for Mental Health and Literacy Skills in Education," vol. 12, no. 3, 2018. https://doi.org/10.3991/ijim.v12i3.8038

[35] Abdalla Eldow, Mohanaad Shakir, and mohamad Yahya Abdu, "Using Information Communication Technology as a Teaching tool in Sudanese Governmental Universities of Khartoum State," International Journal on Informatics Visualization, vol. 1, 2017. https://doi.org/10.30630/joiv.1.4.55

[36] Tawafak, Ragad M., et al. "Assessing the impact of technology learning and assessment method on academic performance." EURASIA Journal of Mathematics, Science and Technology Education 14.6 (2018): 2241-2254.

[37] Tawafak R. M., Mohammed M. N, and Arshah R. B. A, "Review on the Effect of Student Learning Outcome and Teaching Technology in Omani's Higher Education Institution's Academic Accreditation Process," in International Conference on Software and Computer Applications, 2018. https://doi.org/10.1145/3185089.3185108

[38] Tawafak, Ragad M., et al. "Technology enhancement learning reflection on improving students' satisfaction in Omani universities." Advanced Science Letters 24.10 (2018): 77517757. https://doi.org/10.1166/asl.2018.13012

[39] Tawafak, Ragad M., Awanis BT Romli, and Ruzaini Bin Abdullah Arshah. "Continued Intention to use UCOM: Four factors for integrating with a technology acceptance model to 
moderate the Satisfaction of Learning." IEEE Access 6 (2018): 66481-66498. https://doi.org/10.1109/access.2018.2877760

[40] P., Pyke, J., \& Anwar, a Ifinedo, "Business undergraduates' perceived use outcomes of Moodle in a blended learning environment: The roles of usability factors and external support," vol. 35, no. 1 (93-102), 2018. https://doi.org/10.1016/j.tele.2017.10.001

[41] L., Zhang, J., \& Liu, Y Huang, "Antecedents of student MOOC revisit intention: Moderation effect of course difficulty," vol. 37, no. (2), 84-91, 2017. https://doi.org/10. 1016/j.ijinfomgt.2016.12.002

[42] M., Elsherif, H. M., \& Shaalan, K Al-Emran, "Investigating attitudes towards the use of mobile learning in higher education," Computers in Human Behavior, vol. 56, pp. 93-102., 2016. https://doi.org/10.1016/i.chb.2015.11.033

[43] R., \& Knezek, G Christensen, "Readiness for integrating mobile learning in the classroom: Challenges, preferences and possibilities," Computers in Human Behavior, vol. 76, pp. 112121, 2017. https://doi.org/10.1016/j.chb.2017.07.014

[44] GHALIYA ALFARSI, ABDALGADER, KHALED OMAR, and MARYAM ALSINANI, "A rule-based system for advising undergraduate students," vol. 95, no. 11, 2017.

[45] Ghaliya ALFarsi and Maryam ALSinani, "Developing a Mobile Notification System for AlBuraimi University College Students," vol. 1, no. 1, 2017.

[46] Anik Ghufron, Hartono Hendra Erik Rudyanto, "Use of Integrated Mobile Application with Realistic Mathematics Education: A Study to Develop Elementary Students' Creative Thinking Ability," International Journal of Interactive Mobile Technologies (iJIM), vol. 13(10), pp. 19-26, 2019. https://doi.org/10.3991/ijim.v13i10.11598

[47] Nasser Alzeidi, Ghaliya AlFarsi, Mayyada Al Hammoshi, Munesh Singh Chauhan Abir Al Sideiri, "CUDA implementation of fractal image compression," Journal of Real-Time Image Processing, no. ISSN 1861-8200, p. 15, 24 June 2019. https://doi.org/10.1007/ $\underline{\text { s11554-019-00894-7 }}$

[48] Sohail Iqbal, Roy Mathew, Rim Al-Nuaimi, and Abir Al-Sideiri, "Learning problem solving skills: Comparison of E-learning and M-learning in an introductory programming course.," Education and Information Technologies, Springer, 2019. https://doi.org/10. 1007/s10639-019-09896-1

[49] Tawafak, Ragad M., et al. "A systematic review of personalized learning: Comparison between E-learning and learning by coursework program in Oman." International Journal of Emerging Technologies in Learning (iJET) 14.09 (2019): 93-104. https://doi.org/10. 3991/ijet.v14i09.10421

[50] Tawafak, Ragad M., Awanis BT Romli, and Maryam Alsinani. "E-learning system of UCOM for improving student assessment feedback in Oman higher education." Education and Information Technologies 24.2 (2019): 1311-1335. https://doi.org/10.1007/s10639-0189833-0

[51] Tawafak, Ragad M., Sohail Iqbal Malik, and Ghaliya Alfarsi. "Development of Framework from Adapted TAM with MOOC Platform for Continuity Intention." Development 29.1 (2020): 1681-1691.

[52] Tawafak, Ragad M., et al. "Framework design of university communication model (UCOM) to enhance continuous intentions in teaching and e-learning process." Education and Information Technologies (2019): 1-27. https://doi.org/10.1007/s10639-019-09984-2

[53] Al Farsi, Ghaliya, Jasiya Jabbar, and Ragad M. Tawafak. "A Review on Models of Human Face Verification Techniques." 2019 International Conference on Fourth Industrial Revolution (ICFIR). IEEE, 2019. https://doi.org/10.1109/icfir.2019.8894783 
[54] Alfarsi, G., Jabbar, J., Tawafak, R. M., Malik, S. I., Alsidiri, A., \& Alsinani, M. Using Cisco Packet Tracer to simulate Smart Home. https://doi.org/10.1109/acit47987. $\underline{2019.8990975}$

[55] Eldow, Abdalla, et al. "LITERATURE REVIEW OF AUTHENTICATION LAYER FOR PUBLIC CLOUD COMPUTING: A META-ANALYSIS." (2006).

[56] Beranek, M., V. Kováŕ, and V. Vacek. "Design of a learning management system for small and medium sized Universities and Colleges." Proceedings of the International Conference on e-Learning, e-Business, Enterprise Information Systems, and e-Government (EEE). The Steering Committee of The World Congress in Computer Science, Computer Engineering and Applied Computing (WorldComp), 2017.

[57] Mathew, Roy, Sohail Iqbal Malik, and Ragad Moufaq Tawafak. "Teaching Problem Solving Skills using an Educational Game in a Computer Programming Course." Informatics in Education 18.2 (2019): 359. https://doi.org/10.15388/infedu.2019.17

\section{Authors}

Ghaliya Alfarsi got her Master degree in computer science at the University of Sohar in sultanat of Oman in 2015, Bachelor of Science degree in Computer Science at Ajman University, AlAin, United Arab Emarits (UAE) in 2004. she is a lecturer in information technology department in ALBuraimi University College, sultanat of Oman more than twelve years. Most of her publications were indexed under Scopus. her research expertise is in knowledge management, Technology Adoption \& Acceptance, e-learning, face verification and image processing. Email: galfarsi@,buc.edu.om

Hidayah Bet Sulaiman from College of Graduate Studies at University Tenaga Nasional, Putrajaya Campus, Malaysia here PhD from RMIT University, 2011, Masters in Computer Science from University Putra Malaysia, 2006, BSc. (Hons) Information Technology, University Technology MARA, 2001.

Ragad M Tawafak got her Bachelor degree from AlMousel University with an expert system of bacteria classification project. She got with the fifth honour degree in Computer Science. She worked in Software engineering department in AlMustansryia University in Iraq for four years. She worked in Oman College of Management and Technology for two years. Currently, she is a lecturer in information technology department in ALBuraimi College, Oman more than twelve years. Most of her publications were indexed under Scopus. Her current research interests include elearning, Technology Adoption \& Acceptance, Academic Performance.

Jasiya Jabbar attained bachelor degree in Computer Science and Engineering in 2007 from Mahatma Gandhi University, Kerala, India. She obtained her master degree Master of Technology in Software Engineering (2013) under Cochin University of Science and Technology, India. She worked as a lecturer in Information Technology Department in Younus College of Engineering and Central Institute of Technology Private ITI in India for a period of 2 years. She is working as a lecturer in Information Technology department of Al Buraimi University College, Oman since 2016. She has published papers in Artificial Intelligence and Mobile Application areas. Her current research are in areas of authentication, E-learning and Technology adoption. 
Sohail Iqbal Malik he is Head of Information Technology Department, ALBuraimi University College. awarded his $\mathrm{PhD}$ from Australian universities. His current research interests include Algorithmic Thinking, Computer Education, Technology in Education, Problem Solving Skills and Mobile Learning.

Abir Alsidiri is a Master in Computer Science at Sultan Qaboos University in Oman. she is a lecturer in information technology department in ALBuraimi University College, Oman. Most of her publications were indexed under Scopus. Her current research interests include e-learning, m-learning, Technology Adoption \& Acceptance, Academic performance and image processing.

Marym Alsinani is a Master in Computer Science at Sohar University in Oman.

she is a coordinator in information technology department in ALBuraimi University College, Oman. Most of her publications were indexed under Scopus. Her current research interests include e-learning, m-learning, Technology Adoption \& Acceptance.

Article submitted 2019-10-27. Resubmitted 2020-02-26. Final acceptance 2020-02-26. Final version published as submitted by the authors. 


\section{$9 \quad$ Appendix}

Table 1. Statistics

\begin{tabular}{|c|c|c|c|c|c|c|c|}
\hline & Q1 & Q2 & Q3 & Q4 & Q5 & Q6 \\
\hline \multirow[t]{2}{*}{$\mathrm{N}$} & Valid & 35 & 35 & 35 & 35 & 35 & 5 \\
\hline & Missing & 0 & 0 & 0 & 0 & 0 & 0 \\
\hline \multicolumn{2}{|l|}{ Mean } & 3.9500 & 4.5000 & 4.1000 & 4.2000 & 4.0500 & 3.6500 \\
\hline \multicolumn{2}{|c|}{ Std. Error of Mean } & .23480 & .33639 & .17622 & .27720 & .21120 & .15000 \\
\hline \multicolumn{2}{|c|}{ Median } & $1.8000^{\mathrm{a}}$ & $2.1429^{\mathrm{a}}$ & $2.1333^{\mathrm{a}}$ & $2.0000^{\mathrm{a}}$ & $2.0000^{\mathrm{a}}$ & $1.6111^{\mathrm{a}}$ \\
\hline \multicolumn{2}{|l|}{ Mode } & 1.00 & 1.00 & 2.00 & 1.00 & 1.00 & $1.00^{\mathrm{c}}$ \\
\hline \multicolumn{2}{|c|}{ Std. Deviation } & 1.05006 & 1.50438 & .78807 & 1.23969 & .94451 & .67082 \\
\hline \multicolumn{2}{|c|}{ Variance } & 1.103 & 2.263 & .621 & 1.537 & .892 & .450 \\
\hline \multicolumn{2}{|l|}{ Range } & 4.00 & 4.00 & 2.00 & 4.00 & 3.00 & 2.00 \\
\hline \multicolumn{2}{|l|}{ Minimum } & 1.00 & 1.00 & 1.00 & 1.00 & 1.00 & 1.00 \\
\hline \multicolumn{2}{|l|}{ Maximum } & 5.00 & 5.00 & 3.00 & 5.00 & 4.00 & 3.00 \\
\hline \multicolumn{2}{|l|}{ Sum } & 39.00 & 50.00 & 42.00 & 44.00 & 41.00 & 33.00 \\
\hline \multirow[t]{3}{*}{ Percentiles } & 25 & $1.1333^{\mathrm{b}}$ & $1.2500^{\mathrm{b}}$ & $1.3846^{\mathrm{b}}$ & $1.2308^{\mathrm{b}}$ & $1.2308^{\mathrm{b}}$ & $1.0556^{\mathrm{b}}$ \\
\hline & 50 & 1.8000 & 2.1429 & 2.1333 & 2.0000 & 2.0000 & 1.6111 \\
\hline & 75 & 2.6364 & 3.8000 & 2.8000 & 2.9091 & 2.8333 & 2.2727 \\
\hline
\end{tabular}

Table 2. Reliability Statistics

\begin{tabular}{|c|c|c|}
\hline Cronbach's Alpha & Cronbach's Alpha Based on Standardized Items & N of Items \\
\hline .964 & .977 & 6 \\
\hline
\end{tabular}

Table 3. Summary Item Statistics

\begin{tabular}{|l|c|c|c|c|c|c|c|}
\hline & Mean & Minimum & Maximum & $\begin{array}{c}\text { Rang } \\
\mathbf{e}\end{array}$ & $\begin{array}{c}\text { Maximum / } \\
\text { Minimum }\end{array}$ & Variance & $\begin{array}{c}\text { N of } \\
\text { Items }\end{array}$ \\
\hline Item Means & 2.075 & 1.650 & 2.500 & .850 & 1.515 & .079 & 6 \\
\hline $\begin{array}{l}\text { Item } \\
\text { Variances }\end{array}$ & 1.144 & .450 & 2.263 & 1.813 & 5.029 & .445 & 6 \\
\hline $\begin{array}{l}\text { Inter-Item } \\
\text { Covariances }\end{array}$ & .934 & .405 & 1.737 & 1.332 & 4.286 & .128 & 6 \\
\hline $\begin{array}{l}\text { Inter-Item } \\
\text { Correlations }\end{array}$ & .878 & .767 & .945 & .178 & 1.232 & .003 & 6 \\
\hline
\end{tabular}

Table 4. ANOVA

\begin{tabular}{|l|l|c|c|c|c|c|}
\hline \multicolumn{2}{|c|}{} & Sum of Squares & df & Mean Square & F & Sig \\
\hline People & 110.492 & 19 & 5.815 & & \\
\hline \multirow{3}{*}{ Within People } & $\begin{array}{l}\text { Between } \\
\text { Items }\end{array}$ & 7.875 & 5 & 1.575 & 7.49 & .000 \\
\cline { 2 - 7 } & Residual & 19.958 & 95 & .210 & & 7 \\
\cline { 2 - 7 } & Total & 27.833 & 100 & .278 & & \\
\hline Total & 138.325 & 119 & 1.162 & & \\
\hline \multicolumn{7}{|l|}{ Grand Mean $=2.0750$} \\
\hline
\end{tabular}

Table 5. Reliability Statistics

\begin{tabular}{|c|c|c|}
\hline Cronbach's Alpha & $\begin{array}{c}\text { Cronbach's Alpha Based on } \\
\text { Standardized Items }\end{array}$ & N of Items \\
\hline .840 & .955 & 8 \\
\hline
\end{tabular}


Table 6. Inter-Item Correlation Matrix

\begin{tabular}{|l|c|c|c|c|c|c|c|c|}
\hline & Q1 & Q2 & Q3 & Q4 & Q5 & Q6 & Q7 & Q8 \\
\hline Q1 & 1.000 & .223 & .225 & .224 & .220 & .269 & .228 & .272 \\
\hline Q2 & .223 & 1.000 & .876 & .914 & .882 & .830 & .844 & .858 \\
\hline Q3 & .225 & .876 & 1.000 & .910 & .948 & .867 & .931 & .917 \\
\hline Q4 & .224 & .914 & .910 & 1.000 & .920 & .794 & .884 & .925 \\
\hline Q5 & .220 & .882 & .948 & .920 & 1.000 & .866 & .906 & .914 \\
\hline Q6 & .269 & .830 & .867 & .794 & .866 & 1.000 & .898 & .829 \\
\hline Q7 & .228 & .844 & .931 & .884 & .906 & .898 & 1.000 & .906 \\
\hline Q8 & .272 & .858 & .917 & .925 & .914 & .829 & .906 & 1.000 \\
\hline
\end{tabular}

Table 7. Summary Item Statistics

\begin{tabular}{|l|c|c|c|c|c|c|c|}
\hline & Mean & Minimum & Maximum & Range & $\begin{array}{c}\text { Maximum } \\
\text { / Minimum }\end{array}$ & Variance & $\begin{array}{c}\text { N of } \\
\text { Items }\end{array}$ \\
\hline $\begin{array}{l}\text { Inter-Item } \\
\text { Correlations }\end{array}$ & .724 & .220 & .948 & .728 & 4.314 & .082 & 8 \\
\hline
\end{tabular}

Table 8. ANOVA

\begin{tabular}{|c|c|c|c|c|c|c|}
\hline & Sum of Squares & df & Mean Square & $\mathbf{F}$ & Sig \\
\hline \multicolumn{2}{|c|}{ Between People } & 338.597 & 39 & 8.682 & & \\
\hline \multirow{3}{*}{$\begin{array}{r}\text { Withi } \\
\text { n People }\end{array}$} & $\begin{array}{l}\text { Between } \\
\text { Items }\end{array}$ & 26.247 & 7 & 3.750 & 2.707 & .010 \\
\hline & Residual & 378.128 & 273 & 1.385 & & \\
\hline & Total & 404.375 & 280 & 1.444 & & \\
\hline \multicolumn{2}{|l|}{ Total } & 742.972 & 319 & 2.329 & & \\
\hline
\end{tabular}

Table 9. Pre-test Questionnaire

\begin{tabular}{|c|l|}
\hline No. & \multicolumn{1}{|c|}{ Question } \\
\hline 1 & The BUC student traditional system can give easier access and flexibility in attendance follow up \\
\hline 2 & The BUC student system help to fast GPA calculator \\
\hline 3 & Currently, there is difficulty opening the portal to see you a time table for your materials? \\
\hline 4 & Is it difficult to search for a book from the college library site? \\
\hline 5 & There is in BUC map? \\
\hline 6 & $\begin{array}{l}\text { Is the study plan available with you at every moment or prefer an application to return to it any } \\
\text { time? }\end{array}$ \\
\hline
\end{tabular}

Table 10. Post-test Questionnaire

\begin{tabular}{|l|l|l|}
\hline No. & \multicolumn{1}{|c|}{ Questions } & \multicolumn{1}{|c|}{ References } \\
\hline 1 & The Application is very easy in use & $\begin{array}{l}{[24,25,26,27,28,} \\
32]\end{array}$ \\
\hline 2 & The BUC student has a very flexible user interface & {$[28,29,30,32,33]$} \\
\hline 3 & $\begin{array}{l}\text { The Application Support you in how to know your GPA and how to } \\
\text { Calculate }\end{array}$ & {$[4,32,33]$} \\
\hline 4 & $\begin{array}{l}\text { The BUC student application includes a calendar that give a note to } \\
\text { remind you of any important event }\end{array}$ & {$[30]$} \\
\hline 5 & $\begin{array}{l}\text { Does the Application reduce the time for the student to enter the portal } \\
\text { of BUC? }\end{array}$ & $\begin{array}{l}{[24,25,26,31,32,} \\
33]\end{array}$ \\
\hline 6 & The BUC student gives you a news update? & New question \\
\hline 7 & The BUC student helps you to renew a book from the library? & {$[24,26,33]$} \\
\hline 8 & The application has Feedback from a new suggestion the help students? & {$[30,31,32,33]$} \\
\hline
\end{tabular}

